\title{
Faktor-Faktor Penghambat Kelulusan Tepat Waktu Mahasiswa D3 Jurusan Teknik Otomotif Fakultas Teknik Universitas Negeri Padang Tahun Masuk 2016 dan 2017
}

\author{
Yolana Nursyafti $^{1 *}$ dan Wawan Purwanto ${ }^{1}$ \\ ${ }^{1}$ Jurusan Teknik Otomotif, Fakultas Teknik, Universitas Negeri Padang \\ Kampus UNP, Jalan Prof. Dr. Hamka, Air Tawar Padang, Sumatera Barat, Indonesia \\ *e-mail: ylnanur@gmail.com
}

(Diajukan: 18 Juli 2021, direvisi: 26 Juli 2021, disetujui: 30 Juli 2021)

\begin{abstract}
Abstrak
Tujuan dari penelitian ini adalah untuk mengetahui faktor-faktor yang menghambat kelulusan tepat waktu mahasiswa D3 di Jurusan Teknik Otomotif Universitas Negeri Padang dari aspek Fisiologis, Psikologis, Keluarga, Universitas dan Masyarakat. Penelitian berlangsung pada bulan November 2020 sampai dengan Februari 2021. Penelitian ini menggunakan metode penelitian deskriptif dengan analisis faktor konfirmatori. Teknik pengambilan sampel pada penelitian ini menggunakan teknik simple random sampling sedangkan teknik pengumpulan data dalam penelitian ini menggunakan angket atau kuesioner. Bentuk angket disusun menggunakan Skala Likert. Hasil penelitian ini menunjukkan bahwa Variabel Fisiologis (58\%) menjadi faktor yang paling menghambat kelulusan tepat waktu. Setelah dilakukannya analisis faktor konfirmatori terbentuk 2 faktor yang mampu menjelaskan $67.91 \%$ variance dari variabel asli dan sisanya $32.09 \%$ lagi dibentuk oleh variabel lain yang tidak diteliti pada penelitian ini.
\end{abstract}

Kata Kunci: faktor penghambat kelulusan, mahasiswa diploma, fisiologis, psikologis, keluarga, universitas, masyarakat

\begin{abstract}
This study aims to know inhibiting the graduation on time of the Diploma Students in the Departement of Automotive Engineering, Padang State University from Physiology, Psychology, Family, University and society. The study took place from November 2020 to February 2021. This reasearch analyzed using descriptive method by confirmatori factor analyzed. Sample taking techniques in this study is using simple random sampling and data collection technique is using a questionnaire. Physiologi (58\%) be the most inhibiting factor of graduation on time. The analysis of confirmatory factor has formed 2 factors that explain $67.91 \%$ variance of the original variable and $32.09 \%$ variance formed from the others that not researched on this study.
\end{abstract}

Keywords: graduating's delay factor, diploma student, physiology, psychology, family, university, society. 


\section{PENDAHULUAN}

Diploma 3 adalah jenjang pendidikan yang telah dirancang untuk mahasiswa selama 3 tahun dan paling lama 5 tahun, dengan beban studi paling sedikit 108 SKS. Hal tersebut didasarkan peraturan Rektor UNP no. 1 tahun 2018 dan juga tertuang dalam surat pemberitahuan Rektor no. 3434/UN.35/EP/2020. Tugas akhir yang menjadi syarat kelulusan dari jenjang D3 pun tak jauh berbeda dengan diploma lainnya harus menyelesaikan praktik kerja dan juga laporan karya ilmiah. Mata kuliah yang di dapatkan saat kuliah akan lebih banyak praktik dari pada teori. Sebab D3 lebih mengutamakan skill atau kemampuan mahasiswanya. Lulusannya dari jenjang D3 akan memiliki gelar A.Md atau Ahli Madya.

Tabel 1. Beban Studi

\begin{tabular}{cc}
\hline Indeks Prestasi & Beban Studi \\
\hline $0,00-2,00$ & $15 \mathrm{SKS}$ \\
$2,01-3,00$ & $18 \mathrm{SKS}$ \\
$3,01-4,00$ & $20-24 \mathrm{SKS}$ \\
\hline (Sumber : Peraturan Rektor no.1 tahun 2018 pasal 9)
\end{tabular}

Indeks prestasi (IP) menentukan jumlah beban studi yang dapat diikuti oleh mahasiswa di semester selanjutnya. Berdasarkan pada tabel 1 diatas dapat disimpulkan bahwa jika mahasiswa D3 mengambil beban studi sebanyak 18 SKS setiap semesternya, maka sangat mungkin untuk mahasiswa tersebut menyelesaikan studi selama 3 tahun.

Menurut data yang bersumber dari sia2.unp.ac.id kelulusan tepat waktu dari mahasiswa tahun masuk 2016 dan 2017 dapat dilihat pada tabel 2 berikut.

\begin{tabular}{ccc}
\multicolumn{3}{c}{ Tabel 2. Lulusan Tepat Waktu } \\
\hline Tahun Masuk & Mahasiswa Lulus & Jumlah Mahasiswa \\
\hline 2016 & 25 & 67 \\
2017 & 6 & 51 \\
\hline
\end{tabular}

Berdasarkan tabel 2 diatas dapat dilihat dari 67 mahasiswa D3 Teknik Otomotif tahun masuk 2016, hanya 37\% mahasiswa yang lulus tepat waktu, sedangkan mahasiswa D3 Teknik Otomotif tahun masuk 2017 yang bisa menyelesaikan studi tepat 3 tahun hanya $12 \%$ dari jumlah keseluruhan 51 mahasiswa. Dari data tersebut dapat disimpulkan bahwa kelulusan tepat waktu yang diimpikan masih jauh dari kata tercapai.

Terhambatnya kelulusan tepat waktu mahasiswa setidaknya dipengaruhi oleh dua faktor, yaitu ; faktor internal dan faktor eksternal. Adapun faktor internal adalah faktor yang berasal dari diri mahasiswa tersebut, hal ini berupa perihal fisiologis dan psikologis mahasiswa. Sedangkan faktor eksternal adalah faktor yang berasal dari luar atau lingkungan mahasiswa. Hal ini berupa perihal aspek keluarga, aspek universitas dan aspek masyarakat[1].

Berdasarkan pemaparan diatas, peneliti tertarik untuk melakukan penelitian secara mendalam mengenai "Faktor - Faktor Penghambat Kelulusan Tepat Waktu Mahasiswa D3 Jurusan Teknik Otomotif Fakultas Teknik Universitas Negeri Padang Tahun Masuk 2016 dan 2017".

\section{Faktor Internal}

Faktor Internal adalah faktor yang berasal dari diri mahasiswa yang ikut serta dalam mempengaruhi kelulusan tepat waktu mahasiswa. Faktor internal dari setiap mahasiswa tentunya berbeda-beda sesuai dengan karakteristik masing-masing mahasiswa tersebut. Namun, karakteristik tersebut dapat digolongkan menjadi dua aspek besar yaitu : Aspek Fisiologis dan Aspek Psikologis[2]. 


\section{Aspek Fisiologis}

Mahasiswa dituntut untuk menjadi seseorang yang bisa belajar secara aktif dan mandiri di perguruan tinggi. Mahasiswa harus bisa berdiri sendiri dan tidak bergantung kepada orang lain. Untuk bisa melakukan peran tersebut, mahasiswa harus memiliki kondisi jasmani dan tonus (tegangan otot) yang mendukung. Kondisi jasmani yang lemah akan menghambat atau menurunkan kualitas belajar mahasiswa sehingga materi yang dipelajari sulit untuk diikuti. Mengkonsumsi makanan yang bergizi, mengatur istirahat dan olahraga yang cukup dianjurkan untuk menjaga kebugaran jasmani mahasiswa [3].

Proses belajar seseorang tergantung pada kondisi jasmaninya. Jasmani yang sehat tentunya akan mendukung proses belajar. Mahasiswa yang belajar dalam keadaan jasmani yang tidak segar akan mudah merasa kelelahan, lekas mengantuk dan berakhir dengan sulit memahami pelajaran. Maka penting bagi mahasiswa untuk menjaga kebugaran jasmaninya dengan menjalani pola hidup yang sehat. Khususnya bagi mahasiswa teknik yang banyak melakukan praktikum yang membutuhkan tenaga ekstra[4].

Tingkat kepekaan panca indera juga mempengaruhi kecakapan mahasiswa dalam menyerap informasi dan pengetahuan. Daya pendengaran dan penglihatan yang rendah akan menyulitkan mahasiswa dalam mengikuti alur perkuliahan. Akibatnya informasi dan pengetahuan dari dosen, khususnya dikelas tidak dapat terserap dengan baik[4].

\section{Aspek Psikologis}

Aspek Psikologis merupakan keadaan internal yang memberi dampak besar terhadap proses belajar individu. Keadaan psikologis setiap individu memiliki perbedaan. Adanya perbedaan inilah yang menyebabkan cara individu dalam merespons stimulus dari luar berbeda-beda. Hal ini menyebabkan hasil belajar dan pengetahuan dari setiap individu berbeda[4]. Adapun yang dapat digolongkan dalam aspek psikologis adalah Inteligensi, Bakat, Minat dan Motivasi.

Inteligensi merupakan sebuah potensi, sehingga dalam situasi yang sama mahasiswa yang memiliki tingkat inteligensi yang tinggi akan akan lebih berpotensi untuk memperoleh hasil belajar yang lebih optimal. Maka dari itu, mahasiswa dengan inteligensi yang rendah memerlukan bimbingan belajar dari guru atau dosen, orang tua dan lain sebagainya. Selain bimbingan belajar, mahasiswa juga dapat mengoptimalkan hasil belajarnya dengan menambah waktu belajar khusus untuk mendalami pelajaran atau materi yang telah diberikan dosen[5].

Bakat adalah keahlian yang dimiliki seseorang untuk belajar. Keahlian tersebut dapat direalisasikan dalam bentuk yang nyata apabila diasah dan dilatih secara terusmenerus. Apabila seseorang mempelajari suatu bidang yang sesuai dengan bakatnya, maka besar potensinya untuk meraih keberhasilan [5].

Minat didefinisikan sebagai kegemaran seseorang untuk memperhatikan dan melakukan suatu kegiatan secara terus-menerus dengan disertai rasa senang [6]. Belajar dengan minat hasilnya akan lebih baik dari pada belajar tanpa minat. Minat memiliki dampak yang besar terhadap belajar, dengan adanya minat seseorang akan lebih tertarik untuk menguasai apa yang dipelajarinya [7]. Dari uraian ini, dapat disimpulkan bahwa mahasiswa yang memilih jurusan tidak sesuai dengan minatnya akan sulit dalam menekuni jurusan tersebut. Ketidaktekunan tersebut akan menyebabkan kurangnya usaha mahasiswa dalam belajar dan akan berakhir dengan kesulitan dalam menyelesaikan studi tepat waktu.

Motivasi adalah kondisi fisiologis dan psikologis seseorang yang merangsangnya untuk melakukan sesuatu guna menggapai tujuan atau kebutuhan tertentu [8]. Motivasi dalam hal belajar dapat digolongkan menjadi 2 macam, yakni : motivasi intrinsik dan motivasi ekstrinsik. Motivasi intrinsik adalah situasi yang mendorong seseorang untuk 
belajar yang berasal dari dalam diri sendiri. Adapun motivasi ekstrinsik adalah situasi yang juga mendorong seseorang untuk belajar yang berasal dari luar diri individu. Hadiah dan pujian, kebijakan lembaga, persaingan dengan teman sejawat, suri teladan dari orang tua, guru dan tokoh lainnya adalah contoh dari motivasi esktrinsik. Studi di Perguruan Tinggi menuntut mahasiswa untuk memiliki motivasi yang tinggi. Motivasi ini akan mendorong mahasiswa untuk meningkatkan minat, bakat serta kreativitasnya terutama dalam bentuk prestasi. Mahasiswa dengan motivasi tinggi terdorong untuk bersaing dengan mahasiswa lainnya untuk menjadi mahasiswa yang berprestasi dan unggul serta dapat menyelesaikan studi dengan baik dan tepat waktu [9].

\section{Faktor Eksternal}

Faktor Eksternal merupakan aspek - aspek berpengaruh yang berada disekitar atau di luar diri seseorang. Faktor eksternal yang dapat menghambat kelulusan tepat waktu mahasiswa digolongkan pada 3 aspek, yaitu aspek keluarga, universitass dan masyarakat[10].

\section{Aspek Keluarga}

Faktor eksternal yang paling mempengaruhi diri seseorang adalah keluarga. Hal ini dikarenakan individu pertama kali berinteraksi dengan lingkungannya adalah dengan keluarga. Keluarga yang pertama kali mendidik dan mengasuh individu, dengan begitu tentu saja banyak hal dari keluarga yang berdampak pada individu. Hal-hal yang termasuk ke dalam akpek keluarga adalah didikan orang tua, hubungan keluarga dan perekonomian keluarga.

\section{Aspek Universitas}

Universitas merupakan faktor yang tidak kalah penting dalam memberikan pengaruh terhadap kelulusan tepat waktu. Faktor-faktor tersebut berupa beban studi yang belum diselesaikan, relassi dengan dosen dan tugas akhir.

Masyarakat juga berpengaruh terhadap kelulusan tepat waktu. Hal ini terjadi karena mahasiswa tentu saja tidak bisa terlepas dari kehidupan bermasyarakat. Suatu keuntungan bagi individu jika dia beraktivitas dalam masyarakat. Tetapi jika aktivitas yang diikuti mahasiswa terlalu banyak, seperti kegiatan organisasi himpunan, UKM (unit kegiatan mahasiswa), organisasi daerah, organisasi keagamaan dan lain-lain, akan menyebabkan fokus mahasiswa menjadi terbagi. Mahasiswa tidak dapat memaksimalkan usahanya dalam menyelesaikan studi tepat waktu karena tanggung jawab organisasi yang belum terpenuhi[10]. lingkaran pertemanan merupakan hal yang juga sangat mempengaruhi seseorang. Jika seorang mahasiswa berteman dengan mahasiswa yang baik, rajin dan jujur maka mahasiswa tersebut akan dengan mudah tertular dengan sifat tersebut, atau setidaknya mereka akan saling mengingatkan. Akan tetapi jika berteman dengan seseorang yang pemalas, maka besar kemungkinan untuk tertular sifat pemalas tersebut.

\section{Kelulusan Tepat Waktu}

Melanjutkan pendidikan ke perguruan tinggi merupakan impian hampir semua orang. Setelah menyelesaikan masa studi di SMA dan sederajat, orang-orang mulai berbondong-bondong mendaftarkan diri di perguruan tinggi impian. Mereka bahkan jauh hari menyiapkan hal ini dengan mengikuti bimbingan belajar dan les agar bisa lulus seleksi di perguruan tinggi. Setelah diterima di perguruan tinggi, mahasiswa baru ini bersemangat melangkahkan kaki memasuki perguruan tinggi. Mereka mempersiapkan diri untuk menghadapi teman baru, lingkungan baru, dosen baru, serta tugas baru dengan harapan bisa lulus dengan nilai terbaik dan mendapatkan pekerjaan yang baik pula nantinya.

\section{METODE}

\section{Jenis Penelitian}


Pada penelitian ini, jenis penelitian yang digunakan adalah penelitian deskriptif dengan pendekatan korelasional. Penelitian Deskriptif (Descriptive Research) merupakan penelitian yang menggambarkan atau menjelaskan secara faktual mengenai peristiwa yang sedang terjadi tanpa menambahkan suatu hal. Penelitian ini dirancang untuk menemukan informasi dalam suatu keadaan, dimana informasi tersebut dapat menguji hipotesis dari subjek yang diteliti. Data yang akan dideskripsikan adalah faktor-faktor yang akan menghambat kelulusan tepat waktu mahasiswa D3 Jurusan Teknik Otomotif Fakultas Teknik Universitas Negeri Padang tahun masuk 2016 dan 2017.

\section{Waktu dan Tempat Penelitian}

Penelitian ini akan dilakukan di Jurusan Teknik Otomotif Fakultas Teknik Universitas Negeri Padang terkhususnya pada Mahasiswa D3 Jurusan Teknik Otomotif tahun masuk 2016 dan 2017. Waktu penelitian akan di mulai pada bulan November 2020 sampai dengan bulan Maret 2021.

\section{Variabel Penelitian}

Variabel penelitian adalah hal apapun yang ditetapkan oleh peneliti didalam penelitiannya untuk di pahami dan dipelajari sehingga kemudian didapatkan kesimpulannya [11]. Berdasarkan fungsinya variabel dibedakan menjadi beberapa variabel, yang mana pada penelitian ini peneliti menggunakan 2 variabel yaitu variabel bebas (Independent variable) dan variabel terikat (dependent variable). Variabel bebas (independent variable) adalah variabel yang memberikan pengaruh terhadap variabel lain. Sedangkan variabel terikat (dependent variable) adalah variabel yang dipengaruhi oleh variabel bebas [12]. Pada penelitian ini, yang menjadi variabel bebas adalah faktor internal (Fisiologis dan Psikologis) dan faktor ekternal (Keluarga, Sekolah dan Masyarakat) dan yang menjadi variabel terikat adalah kelulusan tepat waktu.

\section{Populasi dan Sampel Penelitian}

Populasi merupakan seluruh subjek atau objek yang memiliki ciri - ciri atau karakteristik tertentu yang menjadi target dari penelitian [13]. Dalam penelitian ini, yang menjadi populasi adalah seluruh mahasiswa D3 Jurusan Teknik Otomotif tahun masuk 2016 dan 2017 yang berjumlah 115 mahasiswa. Tabel 3 akan menunjukkan jumlah populasi penelitian.

Tabel 3. Populasi Penelitian

\begin{tabular}{cc}
\hline Tahun Masuk & Populasi \\
\hline 2016 & 67 Mahasiswa \\
2017 & 48 Mahasiswa \\
Jumlah & 115 Mahasiswa \\
\hline
\end{tabular}

Sering kali tidak semua anggota populasi menjadi pokok penelitian. Peneliti hanya mengambil sebagian dari populasi yang dapat menggambarkan situasi dari tujuan penelitian. Sebagian populasi yang diteliti ini disebut dengan sampel. Jumlah sampel yang diambil minimal 10\% dari jumlah populasi. Untuk menghitung besarnya sampel dalam penelitian ini, peneliti menggunakan rumus dari Slovin berikut ini :

Keterangan :

$$
n=\frac{N}{1+N \cdot e^{2}}
$$

$\mathrm{n}=$ Jumlah Sampel

$\mathrm{N}=$ Jumlah Total Populasi

$\mathrm{e}=$ Batas Toleransi Error

$$
n=\frac{115}{1+115 .(0.1)^{2}}=53.488372
$$


Sampel dalam Penelitian ini dibulatkan menjadi 54 mahasiswa. Sedangkan untuk teknik pemilihan sampel, peneliti menggunakan teknik simple random sampling. Dimana, semua anggota populasi memiliki kesempatan yang sama untuk dijadikan sampel tanpa mengistimewakan anggota populasi tertentu [14].

\section{Instrumen Penelitian}

Instrumen penelitian adalah sarana pembantu yang dipilih oleh peneliti dan mengambil peranan dalam mengumpulkan data penelitian sehingga kegiatan tersebut lebih mudah. Instrumen yang digunakan pada penelitian ini adalah angket data. Angket atau kuesioner merupakan instrumen yang berisi sekumpulan pertanyaan atau pernyataan yang harus ditanggapi oleh responden, dimana peneliti melakukan tanya jawab kepada responden secara tidak langsung [13]. Untuk memudahkan dalam menarik kesimpulan dari setiap pertanyaan yang dimuat dalam angket, maka jawaban yang akan diberikan oleh responden disusun dalam bentuk skala likert seperti yang tertera pada tabel 4 berikut ini :

Tabel 4. Skala Likert

\begin{tabular}{cccc}
\hline No. & Pilihan Jawaban & Bobot Positif & Bobot Negatif \\
\hline 1. & Sangat Setuju (SS) & 5 & 1 \\
2. & Setuju (S) & 4 & 2 \\
3. & Netral (N) & 3 & 3 \\
4. & Tidak Setuju (TS) & 2 & 4 \\
5. & Sangat Tidak Setuju (STS) & 1 & 5 \\
\hline
\end{tabular}

Untuk mendapatkan hasil penelitian yang memuaskan maka peneliti menyusun kisi-kisi instrumen penelitian menjadi butir pertanyaan, seperti terlihat pada tabel 5 berikut :

Tabel 5. Kisi-kisi Instrumen Penelitian.

\begin{tabular}{cccc}
\hline No. & Variabel & Indikator & No. Item \\
\hline 1. & $(\mathrm{X} 1)$ & Jasmani & $1,2,3,4,5$ \\
& Fisiologis & Panca Indra & 6,7 \\
& & Inteligensi & $8,9,10$ \\
2. & Bakat & $11,12,13$ \\
& Psikologis & Minat & $14,15,16,17$ \\
& & Motivasi & $18,19,20,21$ \\
3. & Didikan & Hubungan & $22,23,24$ \\
& Keluarga & Perekonomian & $25,26,27$ \\
4. & Beban Studi & $28,29,30,31$ \\
& Universitas & Dosen & $32,33,34,35$ \\
& $(X 5)$ & Tugas Akhir & $39,37,38$ \\
5. & Organisasi & $43,44,45,46$ \\
& Masyarakat & Pertemanan & $47,48,49,50$ \\
\hline
\end{tabular}

(Sumber : Affina, 2017; Buansah, 2018; Winardi dkk, 2014)

\section{Deskripsi Data}

Untuk dapat menentukan beberapa hal seperti : mean, median, modus, standar deviasi, skor terendah dan tertinggi serta total nilai, maka diperlukan pendeskripsian data. Teknik analisis statistik akan digunakan untuk mendeskripsikan data yang telah diperoleh. Untuk menganalisis tingkat pencapaian responden, digunakan rumus sebagai berikut :

$$
\text { Persentase }=\frac{\text { perolehan nilai }}{\text { total skor terting gi ideal }} \times 100 \%
$$


Tabel 6. Kriteria Tingkat Capaian Responden

\begin{tabular}{ccc}
\hline No. & Persentase & Kriteria \\
\hline 1. & $90 \%-100 \%$ & Sangat Baik \\
2. & $80 \%-89 \%$ & Baik \\
3. & $65 \%-79 \%$ & Cukup \\
4. & $55 \%-64 \%$ & Kurang \\
5. & $0 \%-54 \%$ & Sangat Kurang \\
\hline
\end{tabular}

\section{Analisis faktor konfirmatori}

Analisis faktor konfirmatori memiliki tujuan untuk mendapatkan hubungan atau keterkaitan antar ketiga faktor variabel $\mathrm{X}_{1}, \mathrm{X}_{2}, \mathrm{X}_{3}, \mathrm{X}_{4}$ dan $\mathrm{X}_{5}$ sehingga menghasilkan satu atau lebih variabel baru yang disebut dengan faktor yang tetap menggambarkan variabel sebelumnya. Analisis faktor konfirmatori pada penelitian ini akan dilakukan dengan menggunakan program SPSS versi 25.00 [15].

\section{Teknik Analisis Data}

Data yang telah terkumpul nantinya akan diolah menggunakan program SPSS versi 25.00 dan Microsoft Excel 2010. Berikut langkah-langkah dalam melakukan analisis :

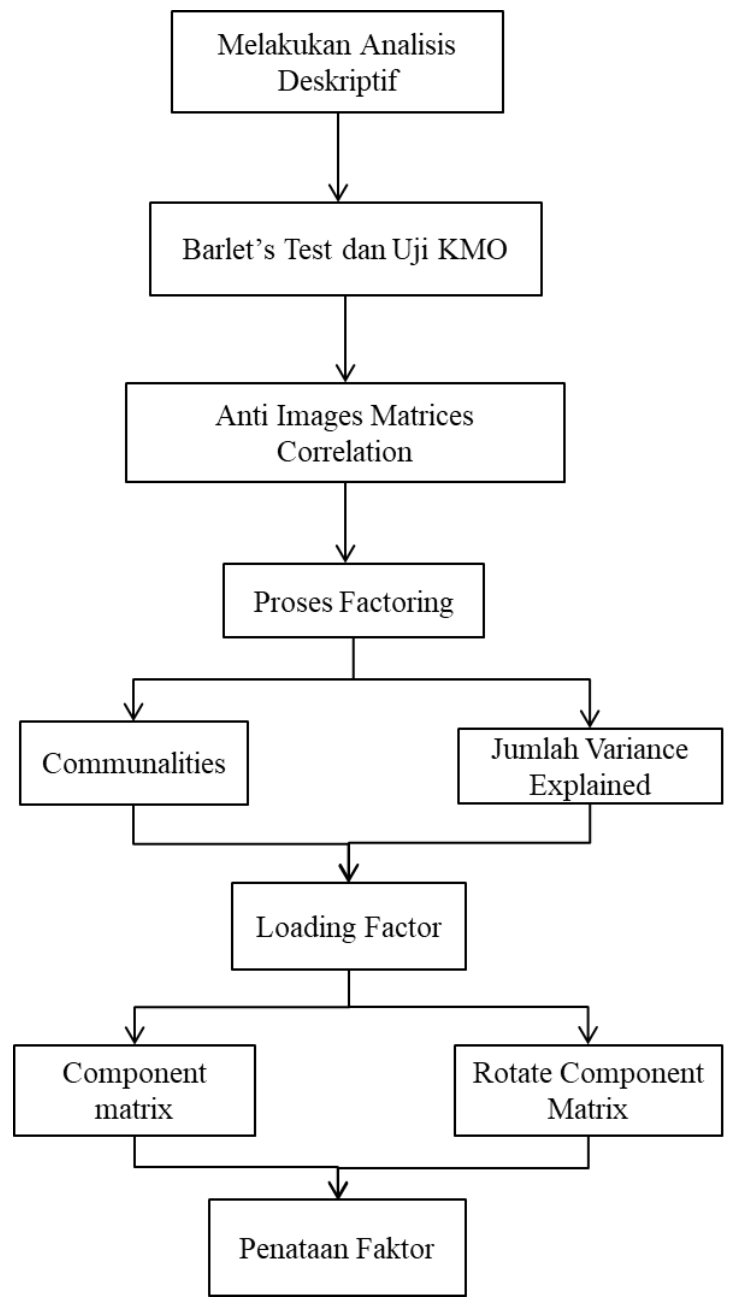

Gambar 1. Kerangka Analisis

\section{HASIL DAN PEMBAHASAN}

\section{Deskripsi Data}


Berdasarkan hasil analisis data yang menggunakan SPSS versi 25.00, variabel yang dapat dideskripsikan secara umum yaitu Fisiologis $\left(\mathrm{X}_{1}\right)$, Psikologis $\left(\mathrm{X}_{2}\right)$, Keluarga $\left(\mathrm{X}_{3}\right)$, Universitas $\left(\mathrm{X}_{4}\right)$ dan Masyarakat $\left(\mathrm{X}_{5}\right)$.

Tabel 7. Deskripsi Variabel Fisiologis $\left(X_{1}\right)$ beserta histrogramnya

\begin{tabular}{|c|c|c|}
\hline \multicolumn{3}{|c|}{ Statistics } \\
\hline \multicolumn{3}{|c|}{ Fisiologis } \\
\hline $\mathrm{N}$ & Valid & 54 \\
\hline & Missing & 0 \\
\hline & & 19.44 \\
\hline & & 19.00 \\
\hline & & 19 \\
\hline & viation & 6.136 \\
\hline & & 37.648 \\
\hline & & 26 \\
\hline & & 7 \\
\hline & um & 33 \\
\hline $\mathrm{Su}$ & & 1050 \\
\hline
\end{tabular}

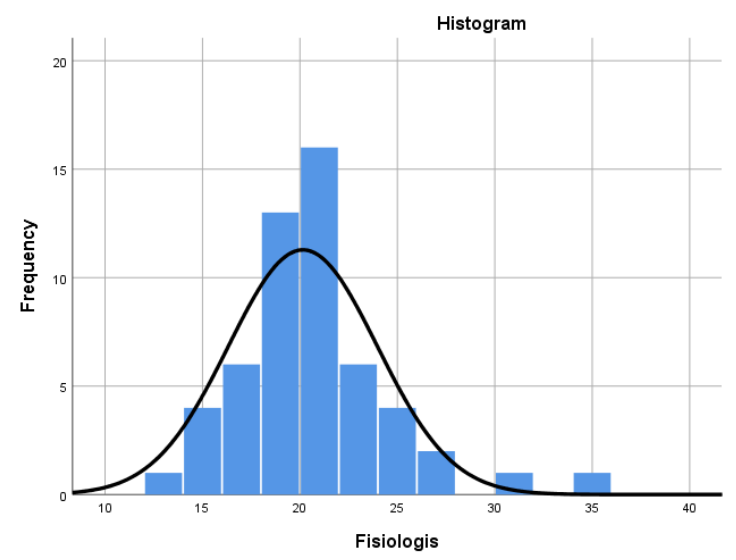

Responden pada penelitian ini adalah sebanyak 54 orang. Berdasarkan jawaban dari responden diperoleh nilai rata-rata (mean) sebesar 19.44, nilai tengah (median) diperoleh 19.00, nilai yang paling banyak muncul (mode) sebesar 19 dan total keseluruhan nilai responden (sum) sebanyak 1050. Persentase Tingkat Capaian Responden yang diperoleh Variabel Fisiologis adalah sebesar $57.78 \%$, persentase ini tergolong dalam kategori kurang.

Tabel 8. Deskriptif Variabel Psikologis $\left(X_{2}\right)$ beserta histogramnya

\begin{tabular}{|c|c|c|}
\hline \multicolumn{3}{|c|}{ Statistics } \\
\hline \multicolumn{3}{|c|}{ Psikologis } \\
\hline \multirow[t]{2}{*}{$\mathrm{N}$} & Valid & 54 \\
\hline & Missing & 0 \\
\hline \multicolumn{2}{|c|}{ Mean } & 39.35 \\
\hline \multicolumn{2}{|c|}{ Median } & 39.00 \\
\hline \multicolumn{2}{|c|}{ Mode } & 32 \\
\hline \multicolumn{2}{|c|}{ Std. Deviation } & 8.883 \\
\hline \multicolumn{2}{|c|}{ Variance } & 78.912 \\
\hline \multicolumn{2}{|c|}{ Range } & 48 \\
\hline \multicolumn{2}{|c|}{ Minimum } & 22 \\
\hline \multicolumn{2}{|c|}{ Maximum } & 70 \\
\hline \multicolumn{2}{|c|}{ Sum } & 2125 \\
\hline
\end{tabular}

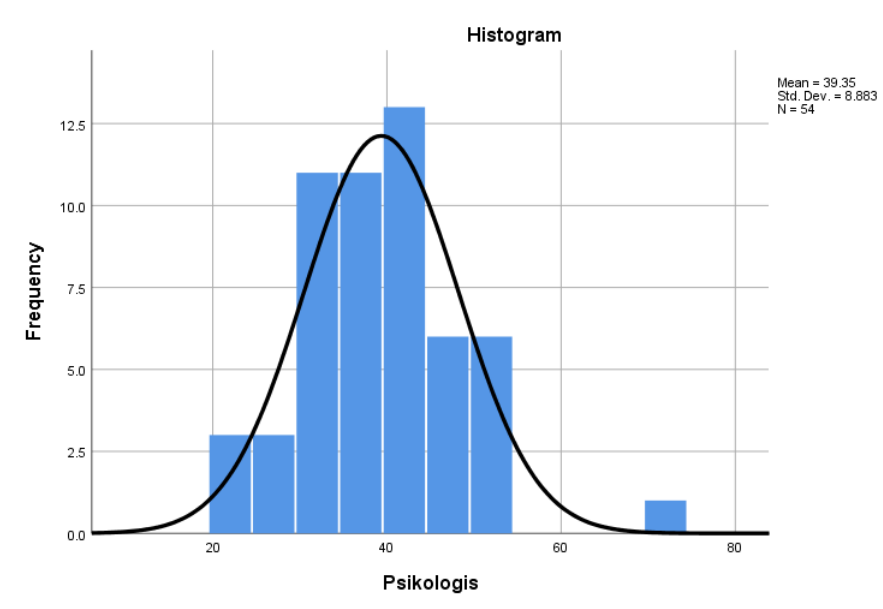

Responden pada penelitian ini adalah sebanyak 54 orang. Dari jawaban responden tersebut diperoleh nilai rata-rata (mean) sebesar 39.35, perolehan nilai tengah (median) sebesar 39.00, nilai yang paling banyak muncul (mode) sebesar 32, perolehan simpang baku (standard deviation) sebesar 8.883, nilai terbesar (maximum) sebesar 70, nilai terkecil (minimum) sebesar 22 dan nilai total dari seluruh responden (sum) sebesar 2125. Persentase Tingkat Capaian Responden yang diperoleh Variabel Psikologis $\left(\mathrm{X}_{2}\right)$ adalah sebesar 56.22\%. Persentase ini tergolong dalam kategori kurang. 
Tabel 9. Deskriptif Variabel Keluarga $\left(X_{3}\right)$

\begin{tabular}{|c|c|c|}
\hline \multicolumn{3}{|c|}{ Statistics } \\
\hline \multicolumn{3}{|c|}{ Keluarga } \\
\hline $\mathrm{N}$ & Valid & 54 \\
\hline & Missing & 0 \\
\hline $\mathrm{Me}$ & & 25.33 \\
\hline & & 26.00 \\
\hline $\mathrm{Mc}$ & & 18 \\
\hline & Iation & 7.294 \\
\hline & & 53.208 \\
\hline & & 32 \\
\hline & & 13 \\
\hline & & 45 \\
\hline $\mathrm{Su}$ & & 1368 \\
\hline
\end{tabular}

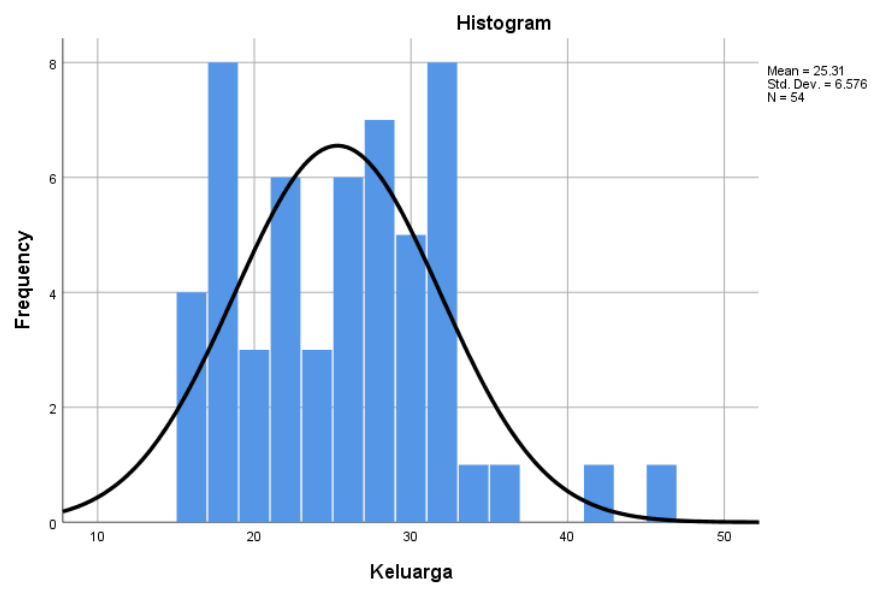

Responden pada variabel ini sebanyak 54 orang. Berdasarkan jawaban responden tersebut diperoleh nilai rata-rata (mean) sebesar 25.33, nilai tengah (median) diperoleh sebesar 26.00, nilai yang paling banyak muncul (mode) 18, simpang baku (standard deviation) sebesar 7.294, nilai terbesar (maximum) 45, nilai terkecil (minimum) 13 dan total keseluruhan nilai responden (sum) sebanyak 1368. Persentase Tingkat Capaian Responden yang diperoleh Variabel Keluarga $\left(\mathrm{X}_{3}\right)$ adalah sebesar $50.63 \%$. Persentase ini tergolong dalam kategori sangat kurang.

Tabel 10. Deskriptif Variabel Universitas $\left(X_{4}\right)$ beserta histogramnya

\begin{tabular}{lr}
\hline \multicolumn{2}{l}{ Statistics } \\
\hline \multicolumn{2}{l}{ Universitas } \\
\hline $\mathrm{N} \quad$ Valid & 54 \\
& Missing \\
Mean & 0 \\
Median & 30.46 \\
Mode & 31.50 \\
Std. Deviation & 33 \\
Variance & 8.202 \\
Range & 67.272 \\
Minimum & 40 \\
Maximum & 12 \\
Sum & 52 \\
\hline
\end{tabular}

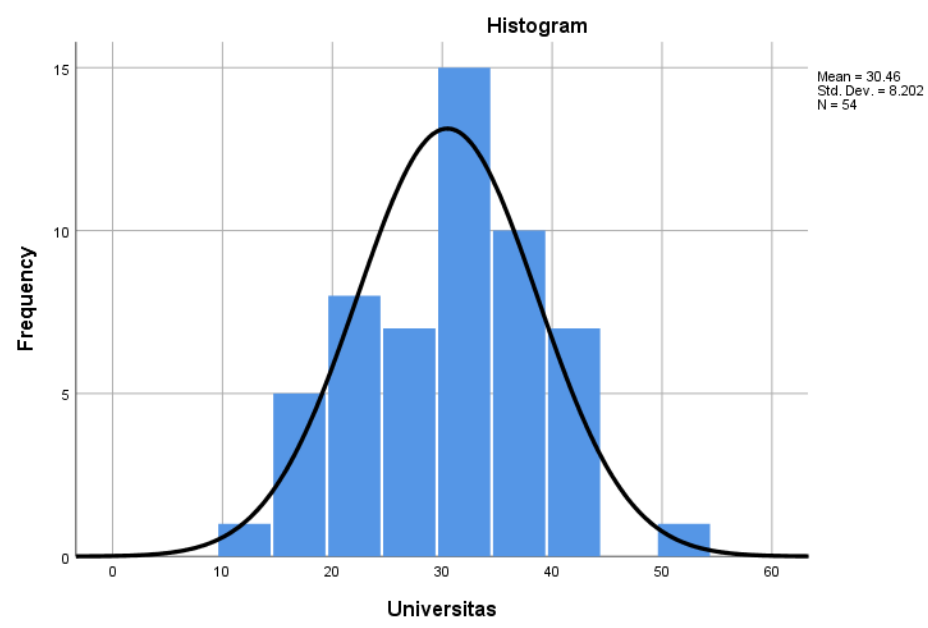

Responden pada variabel ini sebanyak 54 orang. Berdasarkan jawaban dari responden tersebut diperoleh nilai rata-rata (mean) sebesar 30.64, nilai tengah (median) diperoleh 31.50, nilai yang paling sering muncul (mode) adalah 33, simpang baku (standard deviation) sebesar 8.202, nilai terbesar (maximum) 52, nilai terkecil (minimum) diperoleh sebesar 12 dan total seluruh nilai responden (sum) sebanyak 1645. Persentase Tingkat Capaian Responden untuk Variabel Universitas adalah sebesar $55.39 \%$. Persentase ini tergolong dalam kategori kurang. 


\begin{tabular}{|c|c|c|}
\hline \multicolumn{3}{|c|}{$\begin{array}{l}\text { Statistics } \\
\text { Masyarakat }\end{array}$} \\
\hline $\mathrm{N}$ & $\begin{array}{l}\text { Valid } \\
\text { Missing }\end{array}$ & $\begin{array}{l}54 \\
0 \\
\end{array}$ \\
\hline \multicolumn{2}{|c|}{ Mean } & 22.78 \\
\hline \multicolumn{2}{|c|}{ Median } & 23.00 \\
\hline \multicolumn{2}{|c|}{ Mode } & 23 \\
\hline \multicolumn{2}{|c|}{ Std. Deviation } & 5.168 \\
\hline \multicolumn{2}{|c|}{ Variance } & 26.704 \\
\hline \multicolumn{2}{|c|}{ Range } & 26 \\
\hline \multicolumn{2}{|c|}{ Minimum } & 14 \\
\hline \multicolumn{2}{|c|}{ Maximum } & 40 \\
\hline \multicolumn{2}{|c|}{ Sum } & 1230 \\
\hline
\end{tabular}

Responden pada variabel ini adalah sebanyak 54 orang. Berdasarkan jawaban dari responden tersebut diperoleh nilai rata-rata (mean) sebesar 22.78, nilai tengah (median) diperoleh sebesar 23.00, nilai yang paling sering muncul (mode) adalah 23 dan total keseluruhan nilai responden (sum) sebanyak 1230. Persentasi Tingkat Capaian Responden pada Variabel Masyarakat adalah sebesar 56.94\%. Persentase ini tergolong dalam kategori kurang.

\section{Analisis Faktor Konfirmatori}

Tabel 12. Hasil Uji Kelayakan Variabel

\begin{tabular}{|c|c|c|}
\hline \multicolumn{3}{|c|}{ KMO and Bartlett's Test } \\
\hline Kaiser-Meyer-Olkin Measu & ng Adequacy. & .689 \\
\hline \multirow[b]{2}{*}{ Bartlett's Test of Sphericity } & Approx. Chi-Square & 57.110 \\
\hline & $\begin{array}{l}\text { Df } \\
\text { Sig. }\end{array}$ & $\begin{array}{r}10 \\
.000\end{array}$ \\
\hline
\end{tabular}

Berdasarkan tabel 12, dapat diketahui nilai Kaisar Mayer Olkin Measure of Sampling Adequacy pada penelitian ini adalah 0.689 serta nilai signifikansinya 0.000 . Karena nilai tersebut sudah diatas $0.500(0.689>0.500)$ maka variabel layak untuk dianalisis lebih lanjut dan signifikansi kecil dari $0,050(0.000<0.050)$ yang berarti terdapat korelasi yang cukup besar di antara setiap variabel aslinya.

Tabel 13. Uji Anti Image Matrices Correlation

\begin{tabular}{cllllll}
\hline Anti-image Matrices & & & & & \\
\hline & & $\mathrm{X}_{1}$ & $\mathrm{X}_{2}$ & $\mathrm{X}_{3}$ & $\mathrm{X}_{4}$ & $\mathrm{X}_{5}$ \\
\hline \multirow{4}{*}{ Anti-image Covariance } & $\mathrm{X}_{1}$ & .914 & -.161 & .007 & -.017 & .121 \\
& $\mathrm{X}_{2}$ & -.161 & .481 & -.064 & -.254 & -.242 \\
& $\mathrm{X}_{3}$ & .007 & -.064 & .770 & -.138 & -.158 \\
& $\mathrm{X}_{4}$ & -.017 & -.254 & -.138 & .620 & .011 \\
& $\mathrm{X}_{5}$ & .121 & -.242 & -.158 & .011 & .656 \\
Anti-image Correlation & $\mathrm{X}_{1}$ & $.520^{\mathrm{a}}$ & -.242 & .008 & -.022 & .156 \\
& $\mathrm{X}_{2}$ & -.242 & $.646^{\mathrm{a}}$ & -.105 & -.466 & -.430 \\
& $\mathrm{X}_{3}$ & .008 & -.105 & $.819^{\mathrm{a}}$ & -.200 & -.222 \\
& $\mathrm{X}_{4}$ & -.022 & -.466 & -.200 & $.713^{\mathrm{a}}$ & .017 \\
& $\mathrm{X}_{5}$ & .156 & -.430 & -.222 & .017 & $.682^{\mathrm{a}}$ \\
\hline
\end{tabular}

Pada tabel 13 dapat dilihat nilai yang memilki kode "a" merupakan nilai MSA. Nilai Measures of Sampling Adequacy dari setiap variabel menunjukkan angka besar dari 0.500 , dengan begitu semua variabel dinyatakan layak untuk dianalisis lebih lanjut. 
Tabel 14. Hasil Analisis Communalities

\begin{tabular}{c|c|c}
\hline & \multicolumn{3}{c}{ Communalities } \\
\hline & Initial & Extraction \\
\hline $\mathrm{X}_{1}$ & 1.000 & .917 \\
\hline $\mathrm{X}_{2}$ & 1.000 & .745 \\
\hline $\mathrm{X}_{3}$ & 1.000 & .508 \\
\hline $\mathrm{X}_{4}$ & 1.000 & .597 \\
\hline $\mathrm{X}_{5}$ & 1.000 & .628 \\
\hline
\end{tabular}

Berdasarkan tabel 14 dapat dilihat bahwa variabel $\mathrm{X}_{1}$ dapat dijelaskan sebesar $91.7 \%$ oleh faktor yang terbentuk, variabel $\mathrm{X}_{2}$ dapat dijelaskan sebesar $74.5 \%$ oleh faktor yang terbentuk, variabel $\mathrm{X}_{3}$ dapat dijelaskan sebesar $50.8 \%$ oleh faktor yang terbentuk, variabel $\mathrm{X}_{4}$ dapat dijelaskan sebesar $59.7 \%$ oleh faktor yang terbentuk dan variabel $\mathrm{X}_{5}$ dapat dijelaskan sebesar $62.8 \%$ oleh faktor yang terbentuk. Semakin mendekati 1 nilai communities yang diperoleh suatu variabel maka semakin mampu faktor yang terbentuk menjelaskan variance variabel original.

Tabel 15. Hasil Jumlah Variance Explained

\begin{tabular}{|c|c|c|c|c|c|c|c|c|c|}
\hline \multicolumn{10}{|c|}{ Total Variance Explained } \\
\hline \multirow{2}{*}{$\begin{array}{l}\vec{\Xi} \\
\stackrel{\Xi}{\Xi} \\
\stackrel{\Xi}{\Xi} \\
\dot{0}\end{array}$} & \multicolumn{3}{|c|}{ Initial Eigenvalues } & \multicolumn{3}{|c|}{ Extraction Sums of Squared Loadings } & \multicolumn{3}{|c|}{$\begin{array}{c}\text { Rotation Sums of Squared } \\
\text { Loadings }\end{array}$} \\
\hline & Total & $\%$ of Variance & $\begin{array}{c}\text { Cumulative } \\
\%\end{array}$ & Total & $\begin{array}{c}\% \text { of } \\
\text { Variance }\end{array}$ & $\begin{array}{c}\text { Cumulative } \\
\%\end{array}$ & Total & $\%$ of Variance & $\begin{array}{l}\text { Cumula } \\
\text { tive } \%\end{array}$ \\
\hline 1 & 2.371 & 47.424 & 47.424 & 2.371 & 47.424 & 47.424 & 2.286 & 45.728 & 45.728 \\
\hline 2 & 1.024 & 20.482 & 67.906 & 1.024 & 20.482 & 67.906 & 1.109 & 22.178 & 67.906 \\
\hline 3 & .653 & 13.070 & 80.976 & & & & & & \\
\hline 4 & .627 & 12.533 & 93.509 & & & & & & \\
\hline 5 & .325 & 6.491 & 100.000 & & & & & & \\
\hline
\end{tabular}

Berdasarkan tabel 15 dapat dilihat bahwa terdapat 2 faktor yang memiliki nilai eigenvalues $>1$, berarti 2 faktor tesebut yang terbentuk dari serangkaian analisis yang dilalui. Variansi dari faktor 1 adalah $(2.371 / 5) \times 100 \%=47.42 \%$ dari total variance. Variansi dari faktor 2 adalah $(1.024 / 5) \times 100=20.48 \%$ dari total variance. Dengan begitu total variansi kedua faktor tersebut adalah $67.91 \%$ yang dapat diatikan bahwa 2 faktor yang terbentuk tersebut mampu menjelaskan $67.91 \%$ dari variabelitas kelima variabel asli. Sisanya 32.09\% lagi dipengaruhi oleh variabel lain yang tidak diteliti pada penelitian ini.

Tabel 16. Rotate Component Matrix

\begin{tabular}{lcc}
\hline \multicolumn{3}{c}{ Rotated Component Matrix } \\
& \multicolumn{2}{c}{ Component $^{\mathrm{a}}$} \\
\cline { 2 - 3 } & 1 & 2 \\
\hline Fisiologis & .036 & .957 \\
\hline Psikologis & .806 & .309 \\
\hline Keluarga & .711 & -.054 \\
\hline Universitas & .723 & .271 \\
\hline Masyarakat & .779 & -.147 \\
\hline
\end{tabular}

Berdasarkan tabel 16 dapat dilihat bahwa Variabel Fisiologis $\left(\mathrm{X}_{1}\right)$ berkorelasi terbesar dengan faktor 2, maka Variabel Fisiologis dikelompokkan kedalam faktor 2. Sedangkan Variabel Psikologis $\left(\mathrm{X}_{2}\right)$, Keluarga $\left(\mathrm{X}_{3}\right)$, Universitas $\left(\mathrm{X}_{4}\right)$ dan Masyarakat 
$\left(\mathrm{X}_{5}\right)$ berkolerasi terbesar dengan faktor 1, maka variabel-variabel ini dikelompokkan kedalam faktor 1 .

Tabel 17. Component Transformation Matrix

\begin{tabular}{ccc}
\multicolumn{4}{c}{ Component Transformation Matrix } \\
\hline Component & 1 & 2 \\
1 & .968 & .251 \\
2 & -.251 & .968 \\
\hline
\end{tabular}

Berdasarkan tabel 17 dapat dilihat bahwa nilai Component 1 diperoleh sebesar 0.968 dan Component 2 diperoleh sebesar 0.968. Karena semua Component besar dari 0.500 maka kedua faktor yang terbentuk dapat dikatakan tepat dalam merangkum kelima variabel original.

\section{Pembahasan}

Penelitian ini menghasilkan deskripsi dari faktor-faktor penghambat kelulusan tepat waktu mahasiswa D3 Jurusan Teknik Otomotif Fakultas Teknik Universitas Negeri Padang dengan 5 variabel yaitu Fisiologis $\left(X_{1}\right)$, Psikologis $\left(X_{2}\right)$, Keluarga $\left(X_{3}\right)$, Universitas $\left(\mathrm{X}_{4}\right)$ dan Masyarakat $\left(\mathrm{X}_{5}\right)$.

Tingkat Capaian Responden pada setiap variabel di penelitian ini berbeda-beda. Pada variabel Fisiologis $\left(\mathrm{X}_{1}\right)$ nilai TCR yang diperoleh sebesar $57.04 \%$ yang termasuk dalam kategori kurang. Variabel Psikologis $\left(\mathrm{X}_{2}\right)$ memperoleh nilai TCR sebesar $56.22 \%$ yang mana nilai ini termasuk dalam kategori kurang. Variabel Keluarga $\left(\mathrm{X}_{3}\right)$ memperoleh nilai sebesar $50.63 \%$ dimana nilai ini termasuk dalam kategori sangat kurang. Variabel Universitas $\left(\mathrm{X}_{4}\right)$ memperoleh nilai TCR sebesar 55.39 dimana nilai ini masih termasuk dalam kategori kurang. Variabel Masyarakat $\left(\mathrm{X}_{5}\right)$ memperoleh nilai TCR sebesar 56.94\% dimana nilai ini juga termasuk dalam kategori kurang.

Pada analisis Faktor konfirmatori, seluruh variabel original yang diteliti memperoleh nilai Measures of Sampling Adequacy (MSA) > 0.500 sehingga seluruh variabel original dinyatakan valid atau sahih dan dapat dilakukan analisis lanjutan. Pada analisis Communalities semua variabel memperoleh nilai $>0.500$ maka semua variabel layak untuk dianalisis lebih lanjut. Selanjutnya pada analisis Total Variance Explained terdapat 2 faktor yang terbentuk dengan eigenvalues sebesar 2.371 dan 1.024 yang mana 2 faktor tersebut mampu menjelaskan $67.91 \%$ dari variabelitas kelima variabel original dan sisanya dibentuk oleh variabel lain. Kemudian pada analisis Component Matrix didapatkan bahwa Variabel Fisiologis $\left(\mathrm{X}_{1}\right)$ berkorelasi terhadap faktor 2, sedangkan variabel Psikologis $\left(\mathrm{X}_{2}\right)$, Keluarga $\left(\mathrm{X}_{3}\right)$, Universitas $\left(\mathrm{X}_{4}\right)$ dan Masyarakat $\left(\mathrm{X}_{5}\right)$ berkorelasi terhadap faktor 1 . Selanjutnya dilakukan analisis Rotate Component Matrix untuk mengelompokkan variabel-variabel original kedalam 2 faktor yang terbentuk sehingga didapatkan hasil bahwa Variabel Fisiologis $\left(\mathrm{X}_{1}\right)$ dikelompokkan ke dalam faktor 2 dan Variabel Psikologis $\left(\mathrm{X}_{2}\right)$, Keluarga $\left(\mathrm{X}_{3}\right)$, Universitas $\left(\mathrm{X}_{4}\right)$ dan Masyarakat $\left(\mathrm{X}_{5}\right)$ dikelompokkan ke dalam faktor 1 . Tahap terakhir untuk menentukan kelayakan 2 faktor yang terbentuk dilakukan analisis Component Transformation Matrix dan diperoleh hasil kedua faktor $>0.500$ sehingga kedua faktor terbentuk tersebut dinyatakan valid.

Dari kelima variabel original, Variabel Fisiologis memiliki pengaruh terbesar terhadap penghambat kelulusan tepat waktu mahasiswa D3 Jurusan Teknik Otomotif Fakultas Teknik Universitas Negeri Padang tahun masuk 2016 dan 2017. Hal ini dapat dilihat dari nilai TCR yang telah diperoleh setiap variabel yang diteliti yaitu Variabel Fisiologis, Psikologis, Keluarga, Universitas dan Masyarakat. Hasil penelitian ini melengkapi artikel yang sudah diterbitkan sebelumnya [14]. 


\section{KESIMPULAN DAN SARAN}

Pada analisis faktor konfirmatori didapatkan 2 faktor final yang terbentuk dari kelima variabel original. Variabel Fisiologis $\left(\mathrm{X}_{1}\right)$ dikelompokkan ke dalam faktor 2 sedangkan 4 variabel lainnya digolongkan ke dalam faktor 1.

Total variabelitas kedua faktor yang terbentuk ini adalah sebesar $67.91 \%$ dan sisanya terbentuk dari variabel yang tidak dibahas dan diteliti pada penelitian ini.

Kelima variabel original dapat dikatakan cukup untuk menjelaskan faktor-faktor penghambat ke lulusan tepat waktu mahasiswa D3 Jurusan Teknik Otomotif Fakultas Teknik Universitas Negeri Padang tahun masuk 2016 dan 2017.

Variabel Fisiologis menjadi variabel yang paling berpengaruh dalam penelitian ini. Ringkasan dari variabel fisiologis adalah $57.78 \%$ atau 32 dari 54 mahasiswa D3 tahun masuk 2016 dan 2017 setuju bahwa Faktor Fisiologis menghambat mereka dalam lulus tepat waktu.

\section{REFERENSI}

[1] W. Ahmad "Faktor-faktor yang Mempengaruhi Keterlambatan Penyelesaian Studi Mahasiswa Jurusan Teknik Mesin FPTK UPI," Journal of Mechanical Eng ineering Education, vol. 1, no. 2, 2014.

[2] Karwono and M. Heni, Belajar dan Pembelajaran, Depok : Rajawali Pers, 2018.

[3] S. Muhibbin, Psikologi Belajar, Jakarta : Raja Grifando Persada, 2012.

[4] B. Aprizal, "Faktor-faktor Keterlambatan Studi Mahasiswa Pendidikan Geografi Fakultas Ilmu Sosial Universitas Negeri Padang," Jurnal Buana, vol. 2, no. 2, 2018.

[5] W. Rosmalina, Psikologi Belajar, Jakarta : Rajawali Pers, 2016.

[6] R. Kadek, "Faktor-Faktor yang Mempengaruhi Terhambatnya Penyelesaian Studi Mahasiswa Jurusan Pendidikan Ekonomi Tahun 2012/2013,” vol. 4, no. 1, 2014.

[7] H. Oemar, Proses Belajar Mengajar, Jakarta : PT. Bumi Aksara, 2003.

[8] Djaali, Psikologi Pendidikan, Jakarta : PT. Bumi Aksara, 2012.

[9] D. Pratiwi, "Faktor-Faktor yang Mempengaruhi Masa Studi Mahasiswa Pendidikan Teknik Bangunan Universitas Negeri Jakarta," Jurnal Pendidikan Teknik Sipil, vol. 5, no. 2, 2016.

[10] Slameto, Belajar dan Faktor-faktor yang Mempengaruhinya, Jakarta : Rineka Cipta, 2010.

[11] Sugiyono, Metode Penelitian Kuantitatif, kualitatif dan R\&D, Bandung : Alfabeta, 2011.

[12] Sudaryono, Metode Penelitian Pendidikan, Jakarta : Kencana Prenadamedia Group, 2016.

[13] S. Rostina, Statistika Penelitian Pendidikan, Bandung : Alfabeta, 2016.

[14] E. Ananda and W. Purwanto, "Kendala Penyelesaian Tugas Akhir", AEEJ : Journal of Automotive Engineering and Vocational Education, vol. 2, no. 2, pp. 61-72, Jul. 2021. 
Halaman ini sengaja dikosongkan 